\title{
Synthesis, computational, anticancerous and antiproliferative effects of some copper, manganese and zinc complexes with ligands derived from symmetrical 2,2'-diamino-4,4'-dimethyl-1,1'-biphenyl-salicylaldehyde
}

\author{
Taher S. Ababneh ${ }^{*}$, Mohammad El-Khateeb ${ }^{2}$, Aissar K. Tanash ${ }^{1}$, Tareq M.A. AL-Shboul ${ }^{3}$, \\ Mohammad Jamal A. Shammout ${ }^{4}$, Taghreed M.A. Jazzazi ${ }^{1}$, Mohammad Alomari ${ }^{5}$, Safa Daoud ${ }^{6}$, \\ Wamidh H. Talib ${ }^{7}$ \\ ${ }^{1}$ Department of Chemistry, Yarmouk University, Irbid 21163, Jordan \\ ${ }^{2}$ Chemistry Department, Jordan University of Science and Technology, Irbid 22110, Jordan \\ ${ }^{3}$ Department of Chemistry and Chemical Technology, Tafila Technical University, Tafila, Jordan \\ ${ }^{4}$ Department of Basic and Applied Sciences, Zarqa University College, Al-Balqa Applied University, Al-Salt, Jordan \\ ${ }^{5}$ Department of Chemistry, University of Petra, Amman 961343, Jordan \\ ${ }^{6}$ Department of Pharmaceutical Chemistry and Pharmacognosy, Faculty of Pharmacy, Applied Science Private University, \\ Amman, Jordan \\ ${ }^{7}$ Department of Clinical Pharmacy and Therapeutics, Faculty of Pharmacy, Applied Science Private University, Amman, \\ Jordan \\ "Corresponding author: e-mail: ababnehtaher@hotmail.com
}

\begin{abstract}
Four new symmetrical Schiff bases derived from 2,2'-diamino-4,4'-dimethyl-1,1'-biphenyl-salicylaldehyde have been synthesized and characterized by elemental analysis and different spectroscopic techniques. The reaction of 2,2'-diamino-4,4'-dimethyl-1,1'-biphenyl with two equivalents of 5-tert-butyl-, 3,5-dinitro-, 3,5-dibromo- and 3-tertbutyl-salicylaldehyde yielded 2,2'-bis(5-tert-butyl-salicylideneamino)-4,4'-dimethyl-1,1'-biphenyl (A1) as well as the 3,5-dinitro- (A2), 3,5-dibromo- (A3) and 3-tert-butyl- (A4) substituted derivatives. The tetradentate ligands were then reacted with copper-, manganese- and zinc-acetate producing the tetra-coordinate metal complexes which were characterized by FTIR, UV-Visible spectroscopy, magnetic susceptibility and elemental analysis. Zinc complexes were characterized by $1 \mathrm{H}-\mathrm{NMR}$ spectroscopy. Density functional theory (DFT) calculations at the B3LYP/6-31G(d) level of theory were carried out to fully optimize and examine the molecular geometries of complexes. Subsequently, IR vibrational and UV-Vis absorption spectra were computed and correlated with the observed values and the results are in good agreement with the experimental data. The anticancerous and antiproliferative activity of the A3 ligand and its metal complexes were determined.
\end{abstract}

Keywords: Tetradentate Schiff base, Symmetrical metal complexes, DFT calculation, Spectroscopy, Anticancerous, Antiproliferative.

\section{INTRODUCTION}

Schiff bases are compounds containing $\mathrm{C}=\mathrm{NR}(\mathrm{R}=$ alkyl, aryl) functional group and are excellent ligands that can coordinate and stabilize metal ions with various oxidation states ${ }^{1}$. They can coordinate to metals through the imine nitrogen and other donor groups, which are usually bound to an aldehyde or a ketone ${ }^{2}$.

Schiff bases and their metal complexes have several applications. For instance, Schiff bases are used as catalysts ${ }^{3}$, intermediates in organic synthesis ${ }^{4}$, polymer stabilizers $^{5}$ and in dyes synthesis ${ }^{6}$. On the other hand, Schiff base metal complexes have shown greater biological and pharmaceutical activities compared to the free Schiff base compounds ${ }^{7-11}$. The complexes were found to have a broader application as anti-inflammatory ${ }^{12}$, analgesic ${ }^{13}$, antimicrobial ${ }^{14}$, antitubercular ${ }^{15}$, anticancerous $^{16}$ and antioxidant ${ }^{17}$ agents. Furthermore, Schiff base metal complexes are used as catalysts in many chemical reactions ${ }^{18-19}$. Several Co(II) Schiff base complexes have been used as catalysts in the oxygenation of alkenes ${ }^{20}$. Recently ${ }^{21-23}$, the synthesis, characterization and catalytic applications of new metal complexes coordinated with comparable 2,2'-diamino-1,1'-biphenyl-salicylaldehyde Schiff base derivatives have been reported.

Herein, we present the synthesis of new symmetrical tetradentate Schiff bases obtained from the reaction of two equivalents of salicylaldehyde derivatives with 2,2'-diamino-4,4'-dimethyl-1,1'-biphenyl. The copper-, zinc- and manganese-complexes of the resulting Schiff bases were synthesized and characterized. DFT computational studies were conducted to gain a qualitative insight into the structural features and relative energies of the complexes. These calculations revealed detailed vibrational and UV-Vis spectral data of the title complexes and assignments of the computed bands were proposed. Moreover, the anticancerous and antiproliferative activity of the $\mathbf{A} \mathbf{3}$ ligand and its metal complexes were evaluated.

\section{EXPERIMETNAL PART}

\section{Materials and methods}

The elemental analyses $(\mathrm{C}, \mathrm{H}$ and $\mathrm{N}$ ) were carried out on a Perkin Elmer 240 elemental analyzer. ${ }^{1} \mathrm{H}$ - and ${ }^{13} \mathrm{C}$-NMR spectra were recorded on a Bruker AC 400 spectrometer in $\mathrm{CDCl}_{3}$. Infrared spectra were recorded using $\mathrm{KBr}$ on Bruker FT-IR-4100 spectrometer over the range $4000-400 \mathrm{~cm}^{-1}$. Electronic absorption spectra were recorded on PS-2600 Pasco spectrophotometer in DMSO using $8 \times 10^{-5} \mathrm{M}$ solutions. Magnetic susceptibility measurements were done using a magnetic susceptibility balance (Johnson Mathey). All commercially available substrates were purchased from Sigma Aldrich or Alfa Aesar and used without further purification. 2,2'-Diamino-4,4'-dimethyl-1,1'-biphenyl was prepared according 
to a literature procedure ${ }^{24}$. The entire theoretical modeling of Schiff base complexes was performed using Wavefunction Spartan'18 Parallel Suite on a desktop computer with core $i 7^{25}$.

\section{General procedure for the preparation of $\mathrm{R}\left(\mathrm{NH}_{2}\right)_{2} \mathrm{Me}-$ ${ }_{2}$ biph (A1-A4)}

A mixture of $1.62 \mathrm{mmol}$ of 2,2'-diamino-4,4'-dimethyl-1,1'-biphenyl and $3.24 \mathrm{mmol}$ of salicylaldehyde derivative in absolute ethanol $(15 \mathrm{~mL})$ was stirred at reflux for 3 hr. During the reaction, the corresponding Schiff base was precipitated as a stable colored solid. The solid was collected by filtration, washed with cold ethanol and dried under vacuum. All of these ligands are soluble in $\mathrm{CHCl}_{3}$, DMF and DMSO.

5-tert-Butyl $\left(\mathrm{NH}_{2}\right)_{2} \mathrm{Me}_{2}$ biph, A1 $0.72 \mathrm{~g}$ (83\%). Yellow powder. IR $\left(\mathrm{KBr}, \mathrm{cm}^{-1}\right)$ : $v_{\mathrm{O}-\mathrm{H}} 3048(\mathrm{~b}) ; v_{\mathrm{C}-\mathrm{H}} 2967$ (s); $v_{\mathrm{C}=\mathrm{N}} 1621(\mathrm{~s}) ; v_{\mathrm{C}=\mathrm{C}} 1491$ (s); $v_{\mathrm{C}-\mathrm{O}} 1393$ (s). ${ }^{1} \mathrm{H}-\mathrm{NMR}$ $\left(400 \mathrm{MHz}, \mathrm{CDCl}_{3}\right): \delta 1.17\left(\mathrm{~s}, 18 \mathrm{H}, \mathrm{C}\left(\mathrm{CH}_{3}\right)_{3}\right), 2.37(\mathrm{~s}$, $6 \mathrm{H},\left(\mathrm{CH}_{3}\right), 6.70-7.24(\mathrm{~m}, 12 \mathrm{H}$, aromatic- $\mathrm{H}), 8.44(\mathrm{~s}, 2 \mathrm{H}$, $\mathrm{N}=\mathrm{CH}), 12.33(\mathrm{~s}, 2 \mathrm{H}, \mathrm{OH}) \cdot{ }^{13} \mathrm{C} \mathrm{NMR}\left(100 \mathrm{MHz}, \mathrm{CDCl}_{3}\right)$ : $\delta 162.8(\mathrm{~N}=C \mathrm{H}), 157.6,152.5,145.6,142.4,134.9,132.2$, 127.2, 126.8, 124.8, 122.9, 116.8, 115.1 (aromatic-C), 31.7, $30.6\left(\mathrm{CMe}_{3}\right), 21.3(\mathrm{Me})$. MS (EI, $\left.m / z\right): 533[\mathrm{M}]^{+}$. Melting point: $225-228^{\circ} \mathrm{C}$. Anal. Calc. for $\mathrm{C}_{36} \mathrm{H}_{40} \mathrm{~N}_{2} \mathrm{O}_{2}$ : C, 81.17; H, 7.57; N, 5.26\%. Found: C, 80.89; H, 7.66; N, 5.54\%.

3,5-Dinitro $\left(\mathrm{NH}_{2}\right)_{2} \mathrm{Me}_{2}$ biph, A2 $0.77 \mathrm{~g}$ (79\%). Orange powder. IR (KBr, $\left.\mathrm{cm}^{-1}\right): v_{\mathrm{O}-\mathrm{H}} 3068(\mathrm{~b}) ; v_{\mathrm{C}=\mathrm{N}} 1637$ (s); $v_{\mathrm{C}=\mathrm{C}} 1440(\mathrm{~s}) v_{\mathrm{NO} 2} 1523$ (s), 1482 (s); $v_{\mathrm{C}-\mathrm{O}} 1337$ (s). ${ }^{1} \mathrm{H}-$ NMR (400 MHz, $\left.\mathrm{CDCl}_{3}\right): \delta 2.50$ (s, 6H, $\left(\mathrm{CH}_{3}\right), 7.46-8.71$ (m, 10H, aromatic), $9.46(\mathrm{~s}, 2 \mathrm{H}, \mathrm{N}=\mathrm{CH}), 10.20(\mathrm{~s}, 2 \mathrm{H}$, $\mathrm{OH}) .{ }^{13} \mathrm{C}$ NMR $\left(100 \mathrm{MHz}, \mathrm{CDCl}_{3}\right): \delta 162.1(\mathrm{~N}=\mathrm{CH})$, 154.6, 152.3, 143.8, 142.4, 138.9, 130.9, 129.4, 127.6, 126.3, 125.4, 116.9, 115.7 (aromatic-C), $20.8(\mathrm{Me}) . \mathrm{MS}$ (EI, $m / z): 601[\mathrm{M}]^{+}$. Melting point: $198-201^{\circ} \mathrm{C}$. Anal. Calc. for $\mathrm{C}_{28} \mathrm{H}_{20} \mathrm{~N}_{6} \mathrm{O}_{10}$ : C; 56.00; H, 3.36; N, 14.00\%. Found C; $55.91 ; \mathrm{H}, 3.31 ; \mathrm{N}, 14.06 \%$.

3,5-Dibromo $\left(\mathrm{NH}_{2}\right)_{2} \mathrm{Me}_{2}$ biph, $\mathrm{A3} 1.01 \mathrm{~g}(85 \%)$. Yellow powder. IR (KBr, $\left.\mathrm{cm}^{-1}\right): v_{\mathrm{O}-\mathrm{H}} 3068(\mathrm{~b}) ; v_{\mathrm{C}=\mathrm{N}} 1616(\mathrm{~s})$; $v_{\mathrm{C}=\mathrm{C}} 1458 v_{\mathrm{C}-\mathrm{O}} 1339$ (s); $v_{\mathrm{C}-\mathrm{Br}} 688$ (s). ${ }^{1} \mathrm{H}-\mathrm{NMR}(400$ $\left.\mathrm{MHz}, \mathrm{CDCl}_{3}\right): \delta 2.48\left(\mathrm{~s}, 6 \mathrm{H},\left(\mathrm{CH}_{3}\right), 6.96-7.69(\mathrm{~m}, 10 \mathrm{H}\right.$, aromatic), $8.24(\mathrm{~s}, 2 \mathrm{H}, \mathrm{N}=\mathrm{CH}), 13.42(\mathrm{~s}, 2 \mathrm{H}, \mathrm{OH})$. ${ }^{13} \mathrm{C}$ NMR $\left(100 \mathrm{MHz}, \mathrm{CDCl}_{3}\right): \delta 162.2(\mathrm{~N}=\mathrm{CH}), 156.7$, $156.8,147.5,146.1,135.9,133.5,126.8,125.5,123.8$, 124.3, 116.4, 115.0 (aromatic-C), 21.2 (Me). MS (EI, $\mathrm{m} / \mathrm{z}$ ): $737[\mathrm{M}]^{+}$. Melting point: $240-243^{\circ} \mathrm{C}$. Anal. Calc. for $\mathrm{C}_{28} \mathrm{H}_{20} \mathrm{Br}_{4} \mathrm{~N}_{2} \mathrm{O}_{4}: \mathrm{C} ; 45.69 ; \mathrm{H}, 2.74 ; \mathrm{N}, 3.81 \%$. Found C; $45.59 ; \mathrm{H}, 2.64 ; \mathrm{N}, 3.90 \%$.

3-tert-Butyl $\left(\mathrm{NH}_{2}\right)_{2} \mathrm{Me}_{2}$ biph, $\boldsymbol{A 4} 1.01 \mathrm{~g}$ (85\%). Yellow powder. IR $\left(\mathrm{KBr}, \mathrm{cm}^{-1}\right): v_{\mathrm{O}-\mathrm{H}} 3060(\mathrm{~b}) ; v_{\mathrm{C}-\mathrm{H}} 2951(\mathrm{~s}) ; v_{\mathrm{C}=\mathrm{N}}$ 1630 (s); $v_{\mathrm{C}=\mathrm{C}} 1425 ; v_{\mathrm{C}-\mathrm{O}} 1376$ (s). ${ }^{1} \mathrm{H}-\mathrm{NMR}(400 \mathrm{MHz}$, $\left.\mathrm{CDCl}_{3}\right): \delta 1.27\left(\mathrm{~s}, 18 \mathrm{H}, \mathrm{C}\left(\mathrm{CH}_{3}\right)_{3}\right), 2.36\left(\mathrm{~s}, 6 \mathrm{H},\left(\mathrm{CH}_{3}\right)\right.$, 6.56-7.23 (m, $12 \mathrm{H}$, aromatic- $\mathrm{H}), 8.25(\mathrm{~s}, 2 \mathrm{H}, \mathrm{N}=\mathrm{CH})$, 13.24 (s, $2 \mathrm{H}, \mathrm{OH}) \cdot{ }^{13} \mathrm{C}$ NMR (100 MHz, $\left.\mathrm{CDCl}_{3}\right): \delta 164.9$ $(\mathrm{N}=C \mathrm{H}), 155.9,150.5,144.2,142.3,138.5,131.7,129.8$, 128.4, 126.2, 123.8, 118.4, 116.5 (aromatic-C), 34.2, 33.7 $\left(\mathrm{CMe}_{3}\right), 21.2(\mathrm{Me})$. MS (EI, m/z): $533[\mathrm{M}]^{+}$. Melting point: $226-228^{\circ} \mathrm{C}$. Anal. Calc. for $\mathrm{C}_{36} \mathrm{H}_{40} \mathrm{~N}_{2} \mathrm{O}_{2}$ : C; 80.92; $\mathrm{H}, 7.57 ; \mathrm{N}, 5.26 \%$. Found $\mathrm{C} ; 80.92 ; \mathrm{H}, 7.56 ; \mathrm{N}, 5.38 \%$.

\section{General Procedure for the Preparation of Complexes (CuA1-CuA4), (MnA1-MnA4), (ZnA1-ZnA4)}

To a stirred solution of $1.62 \mathrm{mmol}$ Schiff base in $20 \mathrm{~mL}$ ethanol, $1.62 \mathrm{mmol}$ of copper(II) acetate monohydrate, manganese(II) acetate tetrahydrate or zinc(II) acetate dihydrate was added at room temperature. The reaction mixture was heated for $6 \mathrm{hrs}$ at $60^{\circ} \mathrm{C}$. During the reaction, the corresponding complex was precipitated as a colored solid which was precipitated, filtered, washed with cold ethanol and dried as a stable colored powder. All of these complexes are soluble in $\mathrm{CHCl}_{3}$ and DMSO.

$\mathrm{Cu}(\mathrm{II})$ [5-tert-Butyl $\left(\mathrm{NH}_{2}\right)_{2} \mathrm{Me}_{2}$ biph], $\mathrm{CuA1} 0.79 \mathrm{~g} \mathrm{(76 \% ).}$ Green powder. IR $\left(\mathrm{KBr}, \mathrm{cm}^{-1}\right): v_{\mathrm{C}-\mathrm{H}} 2967(\mathrm{~s}) ; v_{\mathrm{C}=\mathrm{N}} 1606$ $(\mathrm{s}) ; v_{\mathrm{C}=\mathrm{C}} 1590(\mathrm{~s}) ; v_{\mathrm{C}-\mathrm{O}} 1385(\mathrm{~s}) ; v_{\mathrm{M}-\mathrm{O}} 590(\mathrm{~m}) ; v_{\mathrm{M}-\mathrm{N}} 450$ (w). MS (EI, m/z): $595[\mathrm{M}]^{+}$. Melting point: $245-248^{\circ} \mathrm{C}$. Anal. Calc. for $\mathrm{CuC}_{36} \mathrm{H}_{38} \mathrm{~N}_{2} \mathrm{O}_{2}: \mathrm{C} ; 72.76 ; \mathrm{H}, 6.45 ; \mathrm{N}$, 4.71\%. Found C; 71.98; H, 6.85; N, 4.59\%.

$\mathrm{Cu}(\mathrm{II})$ [3,5-Dinitro $\left(\mathrm{NH}_{2}\right)_{2} \mathrm{Me}_{2}$ biph], $\mathrm{CuA2} 0.83 \mathrm{~g}(77 \%)$. Green powder. IR $\left(\mathrm{KBr}, \mathrm{cm}^{-1}\right): v_{\mathrm{C}=\mathrm{N}} 1614(\mathrm{~s}) ; v_{\mathrm{C}=\mathrm{C}} 1467$ $(\mathrm{s}) ; v_{\mathrm{NO} 2} 1530,1472(\mathrm{~s}) ; v_{\mathrm{C}-\mathrm{O}} 1327(\mathrm{~s}) ; v_{\mathrm{M}-\mathrm{O}} 533(\mathrm{~m})$; $v_{\mathrm{M}-\mathrm{N}} 443(\mathrm{w})$. MS (EI, m/z): $663[\mathrm{M}]^{+}$. Melting point: 295-298 ${ }^{\circ}$ C. Anal. Calc. for $\mathrm{CuC}_{28} \mathrm{H}_{18} \mathrm{~N}_{6} \mathrm{O}_{10}: \mathrm{C} ; 50.80 ; \mathrm{H}$, $2.74 ; \mathrm{N}, 12.69 \%$. Found C; 50.65; H, 2.57; N, $12.78 \%$.

$\mathrm{Cu}(\mathrm{II})$ [3,5-Dibromo $\left(\mathrm{NH}_{2}\right)_{2} \mathrm{Me}_{2}$ biph], $\mathrm{CuA3} 0.94 \mathrm{~g}$ $(73 \%)$. Green powder. IR $\left(\mathrm{KBr}, \mathrm{cm}^{-1}\right): v_{\mathrm{C}=\mathrm{N}} 1582(\mathrm{~s})$; $v_{\mathrm{C}=\mathrm{C}} 1508(\mathrm{~s}) ; v_{\mathrm{C}-\mathrm{O}} 1303(\mathrm{~s}) ; v_{\mathrm{C}-\mathrm{Br}} 698(\mathrm{~s}) ; v_{\mathrm{M}-\mathrm{O}} 533(\mathrm{~s})$; $v_{\mathrm{M}-\mathrm{N}} 442(\mathrm{w})$. MS (EI, m/z): $798[\mathrm{M}]^{+}$. Melting point: 284-287 ${ }^{\circ}$ C. Anal. Calc. for $\mathrm{CuC}_{28} \mathrm{H}_{18} \mathrm{~N}_{2} \mathrm{O}_{2} \mathrm{Br}_{4}$ : C; 42.16; $\mathrm{H}, 2.27 ; \mathrm{N}, 3.51 \%$. Found C; 42.01; H, 2.13; N, 3.49\%.

$\mathrm{Cu}(\mathrm{II})$ [3-tert-Butyl $\left(\mathrm{NH}_{2}\right)_{2} \mathrm{Me}_{2}$ biph], $\mathrm{CuA4} 0.77 \mathrm{~g} \mathrm{(74 \% ).}$ Green powder. IR $\left(\mathrm{KBr}, \mathrm{cm}^{-1}\right): v_{\mathrm{C}-\mathrm{H}} 2958(\mathrm{~s}) ; v_{\mathrm{C}=\mathrm{N}} 1606$ (s); $v_{\mathrm{C}=\mathrm{C}} 1418(\mathrm{~s}) ; v_{\mathrm{C}-\mathrm{O}} 1319$ (s); $v_{\mathrm{M}-\mathrm{O}} 516(\mathrm{~s}) ; v_{\mathrm{M}-\mathrm{N}} 426$ (w). MS (EI, m/z): $596[\mathrm{M}]^{+}$. Melting point: $242-245^{\circ} \mathrm{C}$. Anal. Calc. for $\mathrm{CuC}_{36} \mathrm{H}_{38} \mathrm{~N}_{2} \mathrm{O}_{2}: \mathrm{C} ; 72.76 ; \mathrm{H}, 6.82 ; \mathrm{N}$, 4.71\%. Found C; 71.97; H, 6.82; N, 4.49\%.

$\mathrm{Mn}(\mathrm{II})$ [5-tert-Butyl $\left(\mathrm{NH}_{2}\right)_{2} \mathrm{Me}_{2}$ biph], MnA1 $0.74 \mathrm{~g}(78 \%)$. Bright yellow powder. IR $\left(\mathrm{KBr}, \mathrm{cm}^{-1}\right): v_{\mathrm{C}-\mathrm{H}} 2951(\mathrm{~s})$; $v_{\mathrm{C}=\mathrm{N}} 1606(\mathrm{~s}) ; v_{\mathrm{C}=\mathrm{C}} 1484(\mathrm{~s}) ; v_{\mathrm{C}-\mathrm{O}} 1360(\mathrm{~s}) ; v_{\mathrm{M}-\mathrm{O}} 533(\mathrm{~m}) ;$ $v_{\mathrm{M}-\mathrm{N}} 405(\mathrm{w})$. MS (EI, m/z): $586[\mathrm{M}]^{+}$. Melting point: 223-226 ${ }^{\circ}$ C. Anal. Calc. for $\mathrm{MnC}_{36} \mathrm{H}_{38} \mathrm{~N}_{2} \mathrm{O}_{2}$ : C; 73.83; $\mathrm{H}, 6.54 ; \mathrm{N}, 4.78 \%$. Found C; 73.77; H, 6.51; N, 4.63\%.

$\mathrm{Mn}(\mathrm{II})$ [3,5-Dinitro $\left(\mathrm{NH}_{2}\right)_{2} \mathrm{Me}_{2}$ biph], MnA2 $0.77 \mathrm{~g}(73 \%)$. Bright yellow powder. IR $\left(\mathrm{KBr}, \mathrm{cm}^{-1}\right): v_{\mathrm{C}=\mathrm{N}} 1614$ (s); $v_{\mathrm{NO} 2} 1556,1517(\mathrm{~s}) ; v_{\mathrm{C}=\mathrm{C}} 1467(\mathrm{~s}) ; v_{\mathrm{C}-\mathrm{O}} 1327(\mathrm{~s}) ; v_{\mathrm{M}-\mathrm{O}}$ $533(\mathrm{~m}) ; v_{\mathrm{M}-\mathrm{N}} 443(\mathrm{w})$. MS (EI, m/z): $654[\mathrm{M}]^{+}$. Melting point: $297-300^{\circ} \mathrm{C}$. Anal. Calc. for $\mathrm{MnC}_{28} \mathrm{H}_{18} \mathrm{~N}_{6} \mathrm{O}_{10}$ : C; 51.47; H, 2.78; N, 12.68\%. Found C; 50.77; H, 2.59; $\mathrm{N}, 12.75 \%$.

Mn(II)[3,5-Dibromo $\left(\mathrm{NH}_{2}\right)_{2} \mathrm{Me}_{2}$ biph], MnA3 $0.91 \mathrm{~g}$ $(72 \%)$. Bright yellow powder. IR $\left(\mathrm{KBr}, \mathrm{cm}^{-1}\right): v_{\mathrm{C}=\mathrm{N}} 1598$ (s); $v_{\mathrm{C}=\mathrm{C}} 1458(\mathrm{~s}) ; v_{\mathrm{C}-\mathrm{O}} 1303(\mathrm{~s}) ; v_{\mathrm{C}-\mathrm{Br}} 672(\mathrm{~s}) ; v_{\mathrm{M}-\mathrm{O}} 533$ (s); $v_{\mathrm{M}-\mathrm{N}} 442(\mathrm{w})$. MS (EI, m/z): $790[\mathrm{M}]^{+}$. Melting point: 285-288 ${ }^{\circ}$ C. Anal. Calc. for $\mathrm{MnC}_{28} \mathrm{H}_{18} \mathrm{~N}_{2} \mathrm{O}_{2} \mathrm{Br}_{4}$ : C; 42.62; $\mathrm{H}, 2.30 ; \mathrm{N}, 3.55 \%$. Found C; 41.94; H, 2.24; N, 3.43\%. $\mathrm{Mn}(\mathrm{II})$ [3-tert-Butyl $\left(\mathrm{NH}_{2}\right)_{2} \mathrm{Me}_{2}$ biph], MnA4 $0.70 \mathrm{~g}(74 \%)$. Bright yellow powder. IR $\left(\mathrm{KBr}, \mathrm{cm}^{-1}\right): v_{\mathrm{C}-\mathrm{H}} 2958(\mathrm{~s})$; $v_{\mathrm{C}=\mathrm{N}} 1606(\mathrm{~s}) ; v_{\mathrm{C}=\mathrm{C}} 1426(\mathrm{~s}) ; v_{\mathrm{C}-\mathrm{O}} 1319(\mathrm{~s}) ; v_{\mathrm{M}-\mathrm{O}} 533(\mathrm{~s}) ;$ $v_{\mathrm{M}-\mathrm{N}} 410(\mathrm{w})$. MS (EI, m/z): $586[\mathrm{M}]^{+}$. Melting point: 220-223 $3^{\circ}$. Anal. Calc. for $\mathrm{MnC}_{36} \mathrm{H}_{38} \mathrm{~N}_{2} \mathrm{O}_{2}$ : C; 73.83; $\mathrm{H}, 6.44 ; \mathrm{N}, 4.73 \%$. Found C; 73.27; H, 6.44; N, 4.73\%. $\mathrm{Zn}(\mathrm{II})$ [5-tert-Butyl $\left(\mathrm{NH}_{2}\right)_{2} \mathrm{Me}_{2}$ biph], ZnAl $0.78 \mathrm{~g}(81 \%)$. Yellow powder. IR (KBr, cm $\left.{ }^{-1}\right): v_{\mathrm{C}-\mathrm{H}} 2972(\mathrm{~s}) ; v_{\mathrm{C}=\mathrm{N}}$ $1612(\mathrm{~s}) ; v_{\mathrm{C}=\mathrm{C}} 1491(\mathrm{~s}) ; v_{\mathrm{C}-\mathrm{O}} 1361(\mathrm{~s}) ; v_{\mathrm{M}-\mathrm{O}} 616(\mathrm{~m})$; 
$v_{\mathrm{M}-\mathrm{N}} 479$ (w). ${ }^{1} \mathrm{H}-\mathrm{NMR}\left(400 \mathrm{MHz}, \mathrm{CDCl}_{3}\right): \delta 1.16$ (s, $\left.18 \mathrm{H}, \mathrm{C}\left(\mathrm{CH}_{3}\right)_{3}\right), 2.38\left(\mathrm{~s}, 6 \mathrm{H},\left(\mathrm{CH}_{3}\right), 6.72-7.25(\mathrm{~m}, 12 \mathrm{H}\right.$, aromatic), $8.46(\mathrm{~s}, 2 \mathrm{H}, \mathrm{N}=\mathrm{CH}) \cdot{ }^{13} \mathrm{C}$ NMR $(100 \mathrm{MHz}$, $\left.\mathrm{CDCl}_{3}\right): \delta 168.3(\mathrm{~N}=\mathrm{CH}), 166.5(\mathrm{CO}), 146.8,140.7$, $135.7,133.7,130.8,129.3,128.9,125.6,123.2,121.1$, 116.0 (aromatic-C), 30.0, $23.9\left(\mathrm{CMe}_{3}\right), 20.1(\mathrm{Me}) . \mathrm{MS}$ (EI, m/z): $597[\mathrm{M}]^{+}$. Melting point: $224-227^{\circ} \mathrm{C}$. Anal. Calc. for $\mathrm{ZnC}_{36} \mathrm{H}_{38} \mathrm{~N}_{2} \mathrm{O}_{2}$ : C; 72.54; H, 6.43; N, 4.70\%. Found $\mathrm{C} ; 72.33 ; \mathrm{H}, 6.42 ; \mathrm{N}, 4.64 \%$.

$\mathrm{Zn}(\mathrm{II})$ [3,5-Dinitro $\left(\mathrm{NH}_{2}\right)_{2} \mathrm{Me}_{2}$ biph], ZnA2 $0.87 \mathrm{~g}(81 \%)$. Yellow powder. IR $\left(\mathrm{KBr}, \mathrm{cm}^{-1}\right): v_{\mathrm{C}=\mathrm{N}} 1621(\mathrm{~s}) ; v_{\mathrm{NO} 2}$ $1556,1527(\mathrm{~s}) ; v_{\mathrm{C}=\mathrm{C}} 1421(\mathrm{~s}) ; v_{\mathrm{C}-\mathrm{O}} 1337$ (s); $v_{\mathrm{M}-\mathrm{O}} 544$ (m); $v_{\mathrm{M}-\mathrm{N}} 483$ (w). ${ }^{1} \mathrm{H}-\mathrm{NMR}\left(400 \mathrm{MHz}, \mathrm{CDCl}_{3}\right): \delta 2.34$ (s, $6 \mathrm{H},\left(\mathrm{CH}_{3}\right), 6.94-8.63(\mathrm{~m}, 10 \mathrm{H}$, aromatic), $8.64(\mathrm{~s}, 2 \mathrm{H}$, $\mathrm{N}=\mathrm{CH}) .{ }^{13} \mathrm{C}$ NMR $\left(100 \mathrm{MHz}, \mathrm{CDCl}_{3}\right): \delta 167.1(\mathrm{~N}=\mathrm{CH})$, 165.8 (CO), 145.6, 141.7, 134.9, 132.7, 132.2, 126.8, 125.3, 121.0, 119.6, 118.1, 116.3 (aromatic-C), 20.2 (Me). MS (EI, m/z): $664[\mathrm{M}]^{+}$. Melting point: $300-303^{\circ} \mathrm{C}$. Anal. Calc. for $\mathrm{ZnC}_{28} \mathrm{H}_{18} \mathrm{~N}_{6} \mathrm{O}_{10}$ : C; 50.66; H, 2.73; N, $12.66 \%$. Found C; 50.41; H, 2.51; N, $12.54 \%$.

$\mathrm{Zn}(\mathrm{II})$ [3,5-Dibromo $\left(\mathrm{NH}_{2}\right)_{2} \mathrm{Me}_{2}$ biph], ZnA3 $1.04 \mathrm{~g}(80 \%)$. Yellow powder. IR $\left(\mathrm{KBr}, \mathrm{cm}^{-1}\right): v_{\mathrm{C}=\mathrm{N}} 1604(\mathrm{~s}) ; v_{\mathrm{C}=\mathrm{C}} 1499$ (s); $v_{\mathrm{C}-\mathrm{O}} 1377$ (s); $v_{\mathrm{C}-\mathrm{Br}} 682$ (s); $v_{\mathrm{M}-\mathrm{O}} 544(\mathrm{~s}) ; v_{\mathrm{M}-\mathrm{N}} 438$ (w). ${ }^{1} \mathrm{H}-\mathrm{NMR}\left(400 \mathrm{MHz}, \mathrm{CDCl}_{3}\right): \delta 2.33\left(\mathrm{~s}, 6 \mathrm{H},\left(\mathrm{CH}_{3}\right)\right.$, 6.82-7.68 (m, 10H, aromatic), $8.04(\mathrm{~s}, 2 \mathrm{H}, \mathrm{N}=\mathrm{CH}) .{ }^{13} \mathrm{C}$ NMR $\left(100 \mathrm{MHz}, \mathrm{CDCl}_{3}\right): \delta 168.1(\mathrm{~N}=C \mathrm{H}), 163.6(\mathrm{CO})$, 145.9, 141.3, 139.4, 135.0, 131.5, 127.8, 124.9, 123.2, 120.5, 117.7, 115.6 (aromatic-C), 20.9 (Me). MS (EI, m/z): $800[\mathrm{M}]^{+}$. Melting point: $282-285^{\circ} \mathrm{C}$. Anal. Calc. for $\mathrm{ZnC}_{28} \mathrm{H}_{18} \mathrm{~N}_{2} \mathrm{O}_{2} \mathrm{Br}_{4}: \mathrm{C} ; 42.07 ; \mathrm{H}, 2.27 ; \mathrm{N}, 3.50 \%$. Found C; 42.13; H, 2.26; N, 3.41\%.

$\mathrm{Zn}(\mathrm{II})$ [3-tert-Butyl $\left(\mathrm{NH}_{2}\right)_{2} \mathrm{Me}_{2}$ biph], $\mathbf{Z n A 4} 0.71 \mathrm{~g}(73 \%)$. Yellow powder. IR $\left(\mathrm{KBr}, \mathrm{cm}^{-1}\right): v_{\mathrm{C}-\mathrm{H}} 2968(\mathrm{~s}) ; v_{\mathrm{C}=\mathrm{N}} 1610$ $(\mathrm{s}) ; v_{\mathrm{C}=\mathrm{C}} 1490(\mathrm{~s}) ; v_{\mathrm{C}-\mathrm{O}} 1357(\mathrm{~s}) ; v_{\mathrm{M}-\mathrm{O}} 612(\mathrm{~s}) ; v_{\mathrm{M}-\mathrm{N}} 465(\mathrm{w})$. ${ }^{1} \mathrm{H}-\mathrm{NMR}\left(400 \mathrm{MHz}, \mathrm{CDCl}_{3}\right): \delta 1.26\left(\mathrm{~s}, 18 \mathrm{H}, \mathrm{C}\left(\mathrm{CH}_{3}\right)_{3}\right)$, $2.47\left(\mathrm{~s}, 6 \mathrm{H},\left(\mathrm{CH}_{3}\right), 6.89-7.50(\mathrm{~m}, 12 \mathrm{H}\right.$, aromatic), 8.56 (s, $2 \mathrm{H}, \mathrm{N}=\mathrm{CH}) .{ }^{13} \mathrm{C}$ NMR $\left(100 \mathrm{MHz}, \mathrm{CDCl}_{3}\right): \delta 170.8$ $(\mathrm{N}=C \mathrm{H}), 168.8(\mathrm{CO}), 147.8,142.1,140.1,136.0,132.3$, 131.1, 130.4, 129.7, 127.1, 121.5, 117.1 (aromatic-C), 31.1, $25.6\left(\mathrm{CMe}_{3}\right)$, and $20.6(\mathrm{Me})$. MS (EI, m/z): $586[\mathrm{M}]^{+}$. Melting point: $223-227^{\circ} \mathrm{C}$. Anal. Calc. for $\mathrm{ZnC}_{36} \mathrm{H}_{38} \mathrm{~N}_{2} \mathrm{O}_{2}$ : C; 74.54; H, 6.43; N, 4.70\%. Found C; 72.48; H, 6.38; $\mathrm{N}, 4.57 \%$.

\section{Computational Method}

Schiff base complexes were fully optimized in the gas phase at the B3LYP/6-31G(d) level of theory ${ }^{26-30}$ without any geometry or symmetry constraints. The absence of imaginary frequencies in the vibrational analysis was taken as evidence that the optimized complexes represent stable minimal-energy geometries.

\section{Antiproliferative Assay}

The antiproliferative effect of $\mathbf{A 3}$ ligand and its three metal complexes was determined using 3-(4,5-dimethylthiazol2-yl)-2,5-diphenyltetrazolium bromide(MTT) assay. This assay measures the reduction of MTT by mitochondrial dehydrogenase (of viable cells) to blue formazan product, which reflects the normal function of mitochondria and cell viability. The procedure was performed as previously described ${ }^{31}$. Briefly, MCF-7 (human breast carcinoma cell line), HCT 116 (human colon cancer cell line) as well as Vero (monkey kidney) normal cell lines were cultured in flat bottom 96-well microplates $\left(1.5 \times 10^{4}\right.$ cells per well $)$ in a complete tissue culture medium supplemented with $10 \%$ fetal bovine serum (FBS), $1 \%$ L-glutamine, $1 \%$ penicillin-streptomycin, and $0.1 \%$ gentamycin. These cell lines were selected to test the ability of compounds to target cancers arising from different tissues. Cells were incubated overnight at $37^{\circ} \mathrm{C}$ in a $5 \% \mathrm{CO}_{2}$ enriched atmosphere. Then cells were exposed to increasing concentrations of the ligand or its three metal complexes $(50-320 \mu \mathrm{M})$. After 48 hours of incubation with different compounds, MTT dye was added to the wells according to the instructions in the kit (Sigma-Aldrich, Missouri, USA). After $4 \mathrm{hr}$ incubation with the MTT solution, blue crystals were produced. The reaction was terminated by adding $100 \mu \mathrm{l}$ of the stop solution for $1 \mathrm{hr}$. Reduced MTT (dark blue color) was assayed using microplate reader (Biotek, Winooski, VT, USA) at a wavelength of $550 \mathrm{~nm}$. The percentage of survival was calculated using the following equation:

$\%$ Survival $=$ treated cells absorbance/negative control absorbance $\times 100 \%$

The calculated inhibitory concentration $\left(\mathrm{IC}_{50}\right)$ represents the treatment concentration that showed a lethal effect on $50 \%$ of cells. Cells treated with cisplatin were used as a positive control and those incubated with culture medium alone were used as a negative control.

\section{RESULTS AND DISCUSSION}

\section{Synthesis}

New symmetrical Schiff bases 2,2'-diamino-4,4'-dimethyl-1,1'-biphenyl-salicylaldehyde (A1, A2, A3, and A4) were prepared via the reaction of 2,2'-diamino-4,4'-dimethyl-1,1'-biphenyl with two equivalents of salicylaldehyde derivative: 5-tert-butyl-, 3,5-dinitro-, 3,5-dibromo-, or 3-tert-butyl-salicylaldehyde to produce the desired tetradentate Schiff base ligands, as shown in Scheme 1.

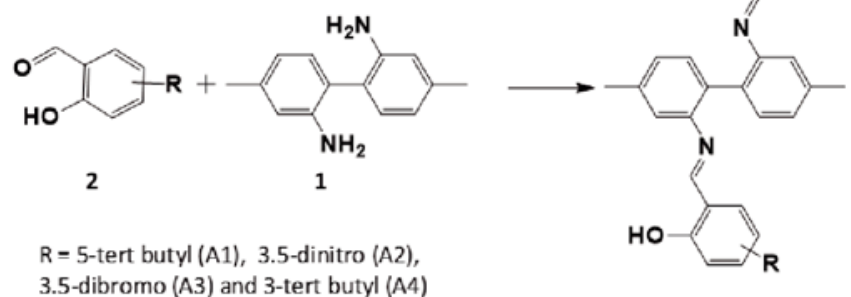

Scheme 1. Synthesis of 2,2'-diamino-4,4'-dimethyl-1,1'-biphenyl-salicylaldehyde Schiff base ligands (A1-A4)

The corresponding copper (CuA1-CuA4), manganese (MnA1-MnA4) and zinc (ZnA1-ZnA4) complexes were prepared by the reaction of copper-, manganese- or zinc-acetate with the corresponding ligands A1-A4 in absolute ethanol as shown in Scheme 2.

Substitution of nitro, bromo, or tert-butyl on the aromatic ring of the salicylaldehyde precursor does not prevent the condensation reaction of 2,2'-diamino4,4'-dimethyl-1,1'-biphenyl with various aldehydes and the corresponding Schiff bases A1-A4 were effectively synthesized with approximately similar yields. 

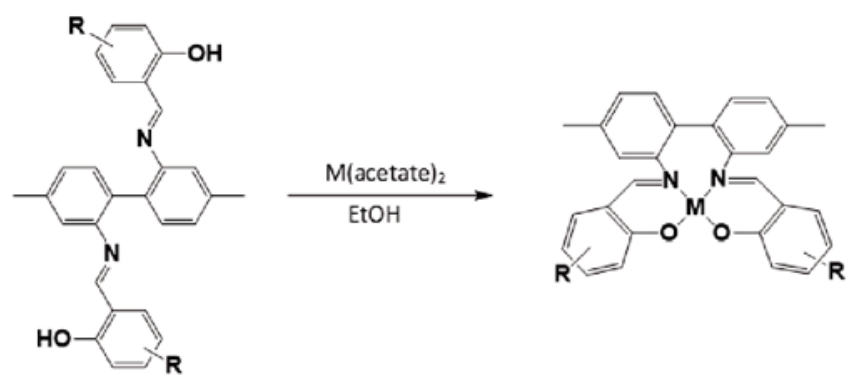

$R=5$-tert butyl (A1), 3.5-dinitro (A2),

3.5-dibromo (A3) and 3-tert butyl (A4)

$\mathrm{M}=\mathrm{Cu}, \mathrm{Mn}, \mathrm{Zn}$

Scheme 2. Synthesis of 2,2'-diamino-4,4'-dimethyl-1,1'-biphenyl-salicylaldehyde metal complexes (CuA1-CuA4), (MnA1-MnA4) and (ZnA1-ZnA4)

\section{Infrared spectroscopy}

Infrared spectra of the prepared copper, manganese and zinc complexes exhibit a shift in the characteristic peak of the imine $(-\mathrm{C}=\mathrm{N}-)$ moiety compared to that of the free ligands, as shown in Table 1.

Table 1. Selected infrared bands of Schiff base ligands and their complexes

\begin{tabular}{|c|c|c|c|c|}
\hline $\begin{array}{c}v(\mathrm{C}=\mathrm{N}) \\
\left(\mathrm{cm}^{-1}\right)\end{array}$ & 1 & 2 & 3 & 4 \\
\hline $\mathrm{A}$ & 1621 & 1637 & 1616 & 1630 \\
\hline $\mathrm{CuA}$ & 1606 & 1614 & 1582 & 1606 \\
\hline $\mathrm{MnA}$ & 1606 & 1614 & 1598 & 1606 \\
\hline $\mathrm{ZnA}$ & 1612 & 1621 & 1604 & 1610 \\
\hline
\end{tabular}

A shift in the position of $v(\mathrm{C}=\mathrm{N})$ is usually an indication of the involvement of this group in the metal coordination $^{21}$. The observed $v(\mathrm{C}=\mathrm{N})$ frequency of the metal complexes is shifted to a lower value indicating complexation from the two azomethine nitrogen atoms.

The broad bands observed in the free ligands (A1-A4) spectra at 3048, 3068, 3065 and $3060 \mathrm{~cm}^{-1}$, respectively, and attributed to the $\mathrm{OH}$ group, disappeared in the case of complexes due to deprotonation and verifying that the Schiff base ligands are also coordinated to the metal ions via phenolic oxygen atoms resulting in a (ONNO)-tetradentate coordination to the metal ions. The normal free $\mathrm{O}-\mathrm{H}$ stretching frequency ranges from $3500-3600 \mathrm{~cm}^{-1}$. However, due to strong intermolecular hydrogen bonding between enolic $\mathrm{O}-\mathrm{H}$ and the nitrogen of the azomethine group $(\mathrm{O}-\mathrm{H}----\mathrm{N})$ the frequencies are reduced to $3048-3060 \mathrm{~cm}^{-1}$.

The weak bands in the lower wavelength regions 401-483 $\mathrm{cm}^{-1}$ (avg. $444 \mathrm{~cm}^{-1}$ ) and 511-616 cm $\mathrm{cm}^{-1}$ (avg. 538 $\mathrm{cm}^{-1}$ ) are assigned to the stretching frequencies of $\mathrm{M}-\mathrm{N}$ and $\mathrm{M}-\mathrm{O}$ bands, respectively, for the metal complexes suggesting the complexation through nitrogen and oxygen atoms from the ligand ${ }^{32-33}$.

\section{UV-Visible spectroscopy}

The UV-Vis electronic spectra of the ligands A1-A4 and complexes in DMSO using $8 \times 10^{-5} \mathrm{M}$ solutions are given in Table 2. Stemming from the conjugated nature of prepared Schiff base ligands, two absorption bands
Table 2. Electronic absorption data of the Schiff base complexes measured at room temperature in DMSO using $8 \times 10^{-5} \mathrm{M}$ solutions

\begin{tabular}{|l|c|c|}
\hline Compound & $\begin{array}{c}\text { Absorption } \\
(\mathrm{nm})\end{array}$ & $\begin{array}{c}\boldsymbol{\varepsilon} \times 10^{3} \\
\left(\mathrm{M}^{-1} \mathrm{~cm}^{-1}\right)\end{array}$ \\
\hline A1 & 275,354 & $12.58,10.33$ \\
\hline A2 & 303,385 & $12.38,28.46$ \\
\hline A3 & 270,358 & $25.08,19.26$ \\
\hline A4 & 274,352 & $24.66,20.42$ \\
\hline MnA1 & 275,388 & $26.00,20.70$ \\
\hline MnA2 & 255,390 & $50.00,28.45$ \\
\hline MnA3 & 257,389 & $25.41,18.96$ \\
\hline MnA4 & 255,389 & $39.41,13.01$ \\
\hline CuA1 & 274,411 & $13.28,5.31$ \\
\hline CuA2 & 261,390 & $48.17,38.77$ \\
\hline CuA3 & 275,390 & $48.25,46.87$ \\
\hline CuA4 & 257,411 & $23.15,7.69$ \\
\hline ZnA1 & 284,388 & $47.62,24.71$ \\
\hline ZnA2 & 260,392 & $42.24,39.30$ \\
\hline ZnA3 & 260,393 & $32.79,14.24$ \\
\hline ZnA4 & 283,390 & $21.86,12.25$ \\
\hline
\end{tabular}

below $450 \mathrm{~nm}$ appeared and were attributed to intra-ligand charge-transfer absorptions; $\pi \rightarrow \pi^{*}$ and $n \rightarrow \pi^{*}$, of the conjugated system and the azomethine group, respectively ${ }^{34}$. These bands also exist in the spectra of all complexes but undergo shifts in absorption peaks especially apparent in the lower-energy band (red shift) of the $n \rightarrow \pi^{*}$ transition. This shift in the spectra of the synthesized complexes supports the coordination of the ligand to metal ions (Fig. 1). Usually, d-d transitions are not easily detected since they may be obscured by the broad charge transfer (CT) transition tailing off into the visible spectra ${ }^{35}$.

\section{NMR spectroscopy}

NMR spectroscopy is utilized to characterize the zinc complexes, whereas copper and manganese complexes were inactive in this spectroscopic technique. The ${ }^{1} \mathrm{H}-\mathrm{NMR}$ spectra of zinc complexes show an absence of $\mathrm{OH}$ proton peaks, which appear at 12.33, 10.20, 13.42 and 13.24 ppm in the free ligands (A1-A4), respectively. This indicates loss of protons from the two hydroxyl groups in the free ligand and possible formation of new bonds between the metal and the two oxygen atoms. Another spectroscopic evidence for the formation of these complexes comes from ${ }^{1} \mathrm{H}-\mathrm{NMR}$ in which characteristic peaks of $(-\mathrm{CH}=\mathrm{N}-)$ proton, which appears at 8.46, 8.64, 8.04 and 8.56 ppm for (ZnA1-ZnA4), respectively, is shifted from 8.44, 9.46, 8.24 and $8.25 \mathrm{ppm}$ in the free ligands (A1-A4), respectively. These ${ }^{1} \mathrm{H}-\mathrm{NMR}$ values for both the free ligands and zinc complexes are compatible with those reported for similar compounds such as 2,2'-bis(2-oxidobenzylideneamino)-4,4'-dimethyldibromo-1,1'-biphenyl derivatives and their corresponding zinc complexes ${ }^{22}$.

\section{Magnetic susceptibility measurements}

The magnetic susceptibility measurements reveal an average effective magnetic moment value for the copper complexes of 1.81 B.M., manganese complexes of 5.93 B.M. and zinc complexes of $\sim 0$ B.M. These values are expected for the dipositive zinc and copper ions in which $\mathrm{Zn}$ (II) with $3 \mathrm{~d}^{10}$ configuration is diamagnetic and $\mathrm{Cu}(\mathrm{II})$ is paramagnetic with one unpaired electron $\left(3 d^{9}\right)$. For $\mathrm{Mn}(\mathrm{II}) 3 \mathrm{~d}^{5}$ configuration, with two possibilities; high-spin 

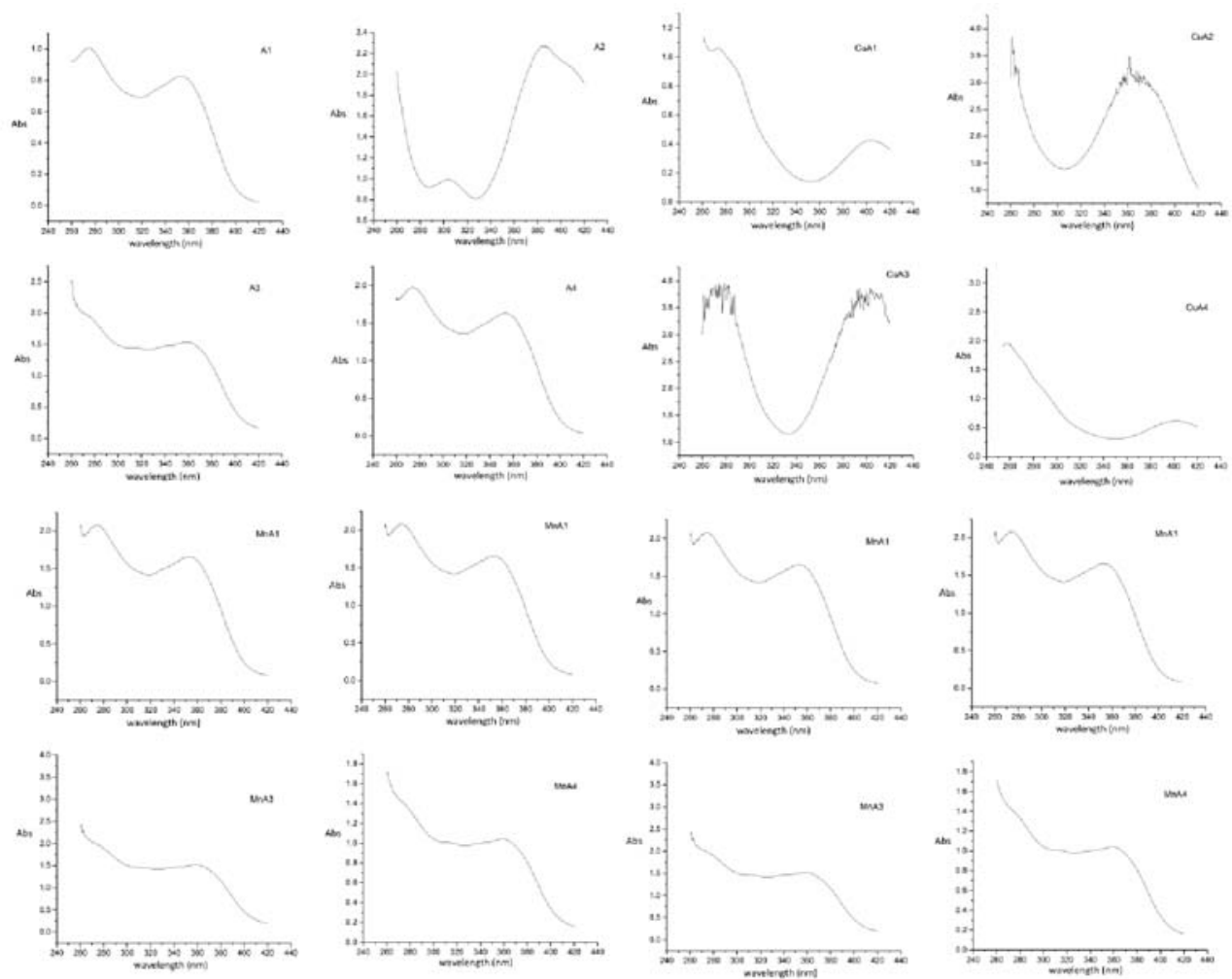

Figure 1. UV-VIS absorption spectra of A1-A4 ligands and their metal complexes at room temperature in $8 \times 10^{-5} \mathrm{M}$ DMSO solutions

(5 unpaired $\mathrm{e}^{-}$) and low-spin (1 unpaired $\mathrm{e}^{-}$) arrangements, the detected magnetic moment of 5.93 B.M., will leave no doubt that the five d-electrons of $\mathrm{Mn}(\mathrm{II})$ are distributed in a high-spin arrangement, which implies that the $\mathrm{Mn}(\mathrm{II})$ complexes would have a tetrahedral-based geometry.

\section{Computational study}

DFT calculations were carried out to investigate the structure, energy and properties of the title neutral monoligated $\mathrm{Cu}, \mathrm{Zn}$ and $\mathrm{Mn}$ complexes at the B3LYP/6$-31 \mathrm{G}(\mathrm{d})$ level of theory. Selected structural parameters of the optimized complexes are listed in Table 3, where bond lengths are in $\AA$ and angles are in degrees.

Table 3. Selected calculated bond lengths (Á) and angles $\left(^{\circ}\right)$ of the complexes

\begin{tabular}{|c|c|c|c|c|c|c|}
\hline & CuA1 & ZnA1 & MnA1 & CuA2 & ZnA2 & MnA2 \\
\hline \multicolumn{7}{|l|}{ Bond $(\AA)$} \\
\hline M-01 & 1.897 & 1.919 & 1.978 & 1.902 & 1.924 & 1.983 \\
\hline M-O2 & 1.900 & 1.921 & 1.981 & 1.901 & 1.924 & 1.983 \\
\hline M-N1 & 1.958 & 2.005 & 2.139 & 1.948 & 1.995 & 2.135 \\
\hline M-N2 & 1.952 & 2.006 & 2.139 & 1.947 & 1.998 & 2.136 \\
\hline $\mathrm{C} 1=\mathrm{N} 1$ & 1.309 & 1.305 & 1.305 & 1.301 & 1.298 & 1.298 \\
\hline $\mathrm{C} 2=\mathrm{N} 2$ & 1.310 & 1.307 & 1.307 & 1.301 & 1.298 & 1.298 \\
\hline O1-M-O2 & 93.68 & 111.43 & 120.19 & 93.79 & 111.11 & 121.13 \\
\hline O1-M-N1 & 94.79 & 95.65 & 89.18 & 94.35 & 94.83 & 87.75 \\
\hline N1-M-N2 & 98.67 & 98.35 & 94.58 & 99.70 & 100.39 & 95.87 \\
\hline N2-M-O2 & 94.79 & 95.45 & 89.17 & 94.45 & 94.67 & 87.79 \\
\hline O1-M-N2 & 144.21 & 129.66 & 134.17 & 143.34 & 129.83 & 134.62 \\
\hline \multirow[t]{2}{*}{ O2-M-N1 } & 143.59 & 129.91 & 133.19 & 143.78 & 129.95 & 133.83 \\
\hline & CuA3 & ZnA3 & MnA3 & CuA4 & ZnA4 & MnA4 \\
\hline M-O1 & 1.902 & 1.921 & 1.982 & 1.904 & 1.921 & 1.978 \\
\hline $\mathrm{M}-\mathrm{O} 2$ & 1.900 & 1.924 & 1.981 & 1.897 & 1.916 & 1.972 \\
\hline $\mathrm{M}-\mathrm{N} 1$ & 1.949 & 2.001 & 2.138 & 1.943 & 1.994 & 2.127 \\
\hline M-N2 & 1.951 & 2.002 & 2.139 & 1.944 & 1.998 & 2.130 \\
\hline $\mathrm{C} 1=\mathrm{N} 1$ & 1.305 & 1.302 & 1.302 & 1.308 & 1.306 & 1.306 \\
\hline $\mathrm{C} 2=\mathrm{N} 2$ & 1.305 & 1.302 & 1.302 & 1.308 & 1.306 & 1.306 \\
\hline \multicolumn{7}{|l|}{ Angle (०) } \\
\hline O1-M-O2 & 94.50 & 112.68 & 122.37 & 95.10 & 111.07 & 120.76 \\
\hline O1-M-N1 & 94.29 & 94.93 & 88.22 & 94.13 & 94.79 & 88.25 \\
\hline N1-M-N2 & 99.14 & 99.38 & 95.12 & 99.47 & 99.17 & 95.04 \\
\hline N2-M-O2 & 94.51 & 94.77 & 88.14 & 94.29 & 94.36 & 87.96 \\
\hline O1-M-N2 & 143.16 & 129.16 & 133.50 & 142.60 & 130.64 & 134.75 \\
\hline O2-M-N1 & 143.82 & 129.33 & 132.53 & 143.47 & 131.05 & 134.21 \\
\hline
\end{tabular}


The optimized geometries of the copper complexes are depicted in Figures 2 and 3. These Figures also elucidate the molecular structures of the $\mathrm{Zn}$ and $\mathrm{Mn}$ complexes since our data suggest an analogous coordination environment around the metal ions. The results from the geometrical optimization of the complexes show that the complexes exhibit the same tetradentate coordination around the metal ion with a distorted geometry.

The $\mathrm{M}(\mathrm{II})$ center $(\mathrm{M}=\mathrm{Cu}, \mathrm{Mn}, \mathrm{Zn})$ is in an intermediate coordination sphere between tetrahedral and planar arrangement of the donor atoms with an average angle between the O1-M-O2 and N1-M-N2 planes of $49.3^{\circ}$, 56.1 and $64.2^{\circ}$ whereas the average angle between the O1-M-N1 and O2-M-N2 planes is $50.1^{\circ}, 64.5^{\circ}$ and $69.5^{\circ}$ for the $\mathrm{Cu}, \mathrm{Mn}$ and $\mathrm{Zn}$ complexes, respectively. This trend is closely attuned to the increase in atomic size across this series of metals.
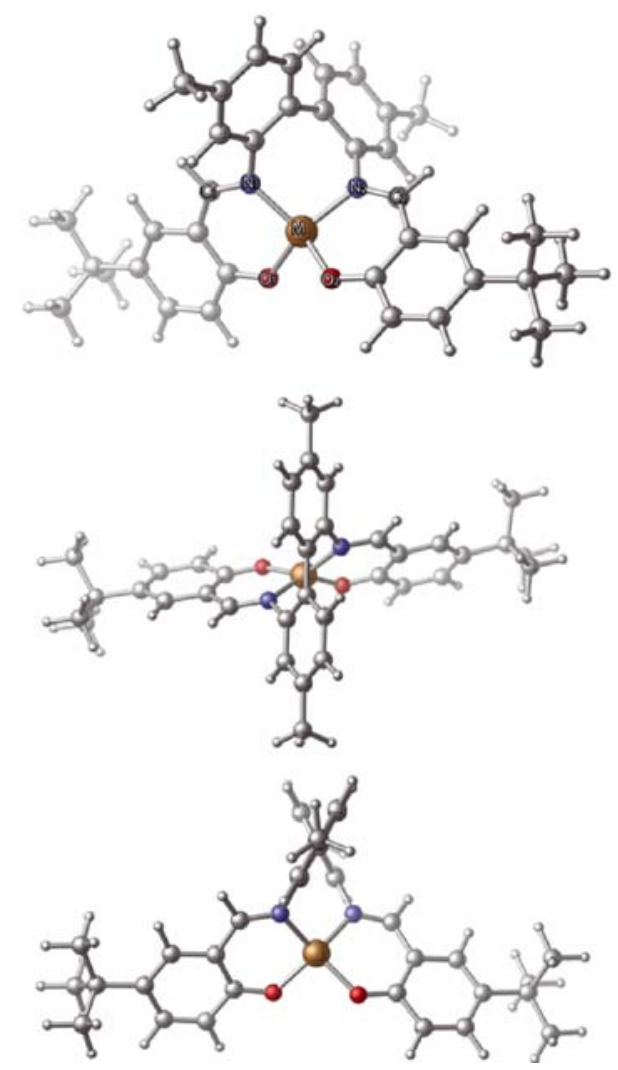

Figure 2. Different views of the optimized ground-state geometry for the copper(II) complex with A1 ligand at the B3LYP/6-31G(d) level of theory showing the atom-numbering scheme around the metal ion

The calculated $\mathrm{C}-\mathrm{C}$ bond length between aryl units of the biphenyl backbone across all twelve complexes exhibits a typical single bond value averaging $1.494 \AA$, thus ruling out interactions between $\pi$-systems of these moieties. This result is close to the reported value of $1.491 \AA$ for a comparable zinc complex ${ }^{22}$ for which the biphenyl backbone is twisted with an angle of $56.5^{\circ}$ between the aryl planes, which is also comparable to an average value of $58.67^{\circ}$ calculated for $\mathbf{Z n A n}(\mathrm{n}=1,2,3)$ complexes. The relatively larger torsion angles in these ligands could be attributed to the lack of bulky groups at the biphenyl backbone allowing for some flexibility in such systems.

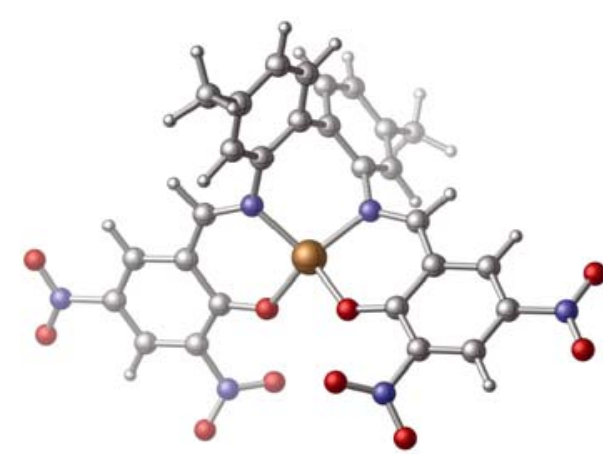

CuA2
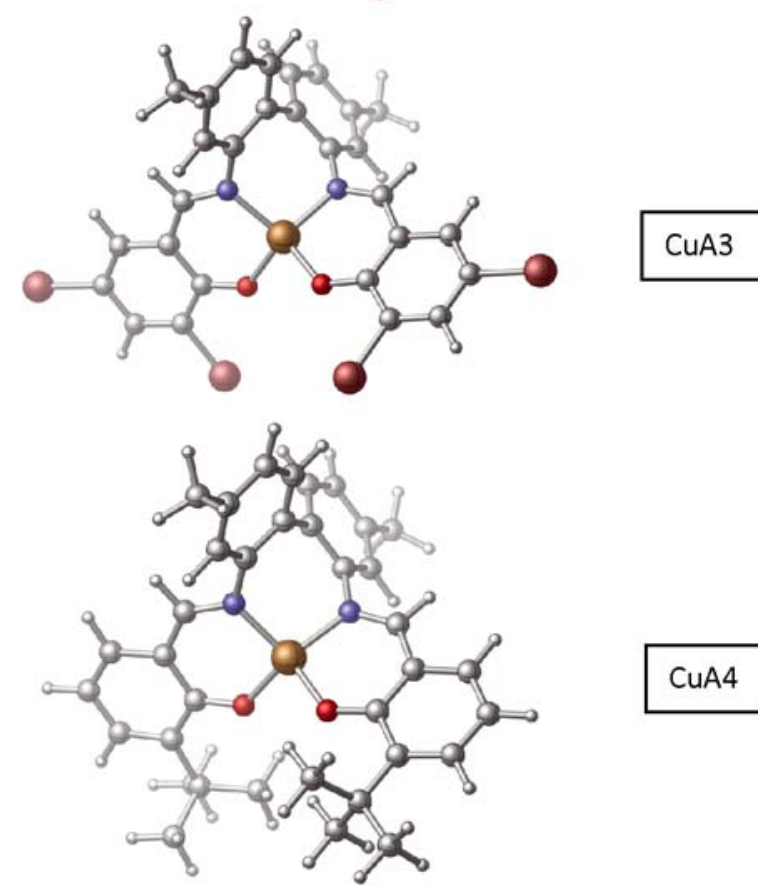

CuA4

Figure 3. Perspective views of the optimized ground-state geometries for the A2, A3 and A4 copper complexes at the B3LYP/6-31G(d) level of theory

In all complexes, the calculated $\mathrm{M}-\mathrm{O}$ bond distance ranges from $1.897-1.983 \AA$ with an average length of $1.934 \AA$, while the computed M-N bond distance ranges from 1.943-2.139 $\AA$ (average of $2.028 \AA$ ). These variations in bond distances are only considered when going from a group of all-copper complexes to another of all-zinc complexes, etc. However, by only taking into account complexes of one metal ion as a group (e.g. $\mathrm{CuA} 1, \mathrm{CuA} 2$, etc.), we can see that such variations in bond distances are minute. For example, average $\mathrm{Cu}-\mathrm{O}$ bond distances in going from $\mathrm{CuA} 1$ to $\mathrm{CuA} 4$ is 1.898 , $1.901,1.900$ and $1.900 \AA$, respectively. This similarity reflects the fact that the coordination environment around the metal ion in the complexes is not directly influenced by the type of substituent on the ligand, but rather by the type of metal ion and its unique electronic configuration. The calculated $\mathrm{Cu}-\mathrm{O}$ and $\mathrm{Cu}-\mathrm{N}$ average bond distances in all investigated copper complexes are 1.900 and $1.949 \AA$, respectively. This result is in good agreement with a similar XRD-resolved copper complex reported recently in our lab $^{\mathbf{3 6}}$ in which the experimental $\mathrm{Cu}-\mathrm{O}$ and $\mathrm{Cu}-\mathrm{N}$ average bond distances are 1.903 and $1.958 \AA$, respectively.

The bond angles of neighboring sites in the $\mathrm{MN}_{2} \mathrm{O}_{2}$ core follow a similar pattern. For example, the average O1-M-O2 angle is calculated at $94.24^{\circ}$ for the $\mathrm{Cu}$ complexes, $111.57^{\circ}$ for the $\mathrm{Zn}$ complexes and $121.11^{\circ}$ 
for the Mn complexes. The geometry generally is based on an arrangement of electron pairs. Since Mn(II) complexes have five unpaired electrons, their d-orbitals are only half filled, thus it demands less space, and the O-M-O angle opens up a little to $121.11^{\circ}$ (on average). The calculated bond angles of $\mathrm{O} 1-\mathrm{Cu}-\mathrm{O} 2\left(94.24^{\circ}\right)$ and $\mathrm{N} 1-\mathrm{Cu}-\mathrm{N} 2\left(99.24^{\circ}\right)$ are considerably similar to the values found in the literature for unsubstituted copper(II) 2,2'-(2-oxidobenzylideneamino)-1,1'-biphenyl $\left(89^{\circ}-96^{\circ}\right)^{37}$.

Other factors that have a significant role in determining the geometry around the metal are steric constraints imposed by the multidentate ligands. These are of particular importance in our case since such large ligands (A1 to A4) force the complex into a distorted geometry so the ligand can be less restraint and confined.

In addition to the ground-state geometrical optimization, calculations on several low-lying excited states (100 states were used) were carried out to produce a UV/visible spectrum. Calculations performed at the B3LYP/6-31G(d) level of theory on the CuA1 complex resulted in an electronic absorption spectrum with $\lambda_{\max }$ of 312 and $395 \mathrm{~nm}$. This result is in good agreement with the experimental $\lambda_{\max }$ of 274 and $411 \mathrm{~nm}$ (Fig. 4).

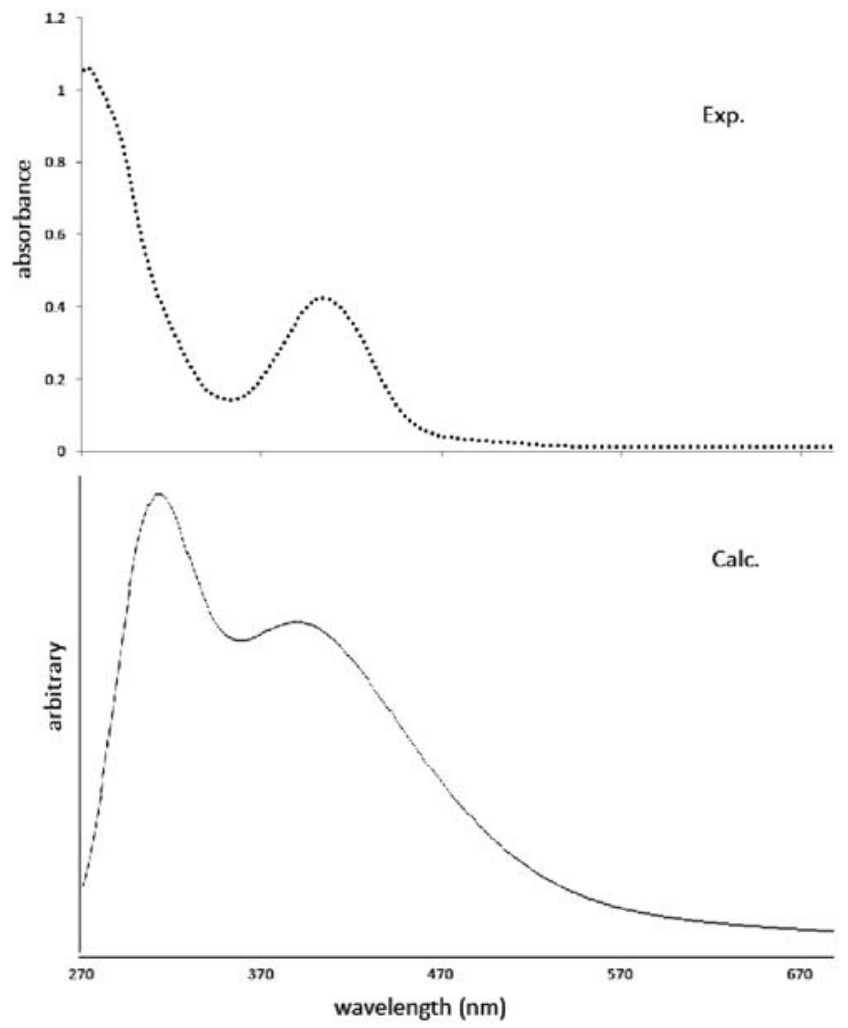

Figure 4. Comparison of DFT-calculated and experimental absorption spectra for the A1-copper complex. $\lambda_{\max }$ : computed $=312,395 \mathrm{~nm}$, experimental $=274$, $411 \mathrm{~nm}$

The vibrational analysis was also conducted in which the IR vibrational wavenumbers were computed and compared with the experimentally determined values. The computed FT-IR vibrational analysis of the ligands (Fig. 5) reveals a strong band at $1608-1610 \mathrm{~cm}^{-1}$ assigned to the $\mathrm{C}=\mathrm{N}$ stretching of the ligands and in good agreement with the experimentally determined IR spectra. Another calculated absorption band at $1561-1577 \mathrm{~cm}^{-1}$ is assigned to the $\mathrm{C}=\mathrm{C}$ stretching mode. The broad band observed in the $3048-3068 \mathrm{~cm}^{-1}$ region in the IR spectrum

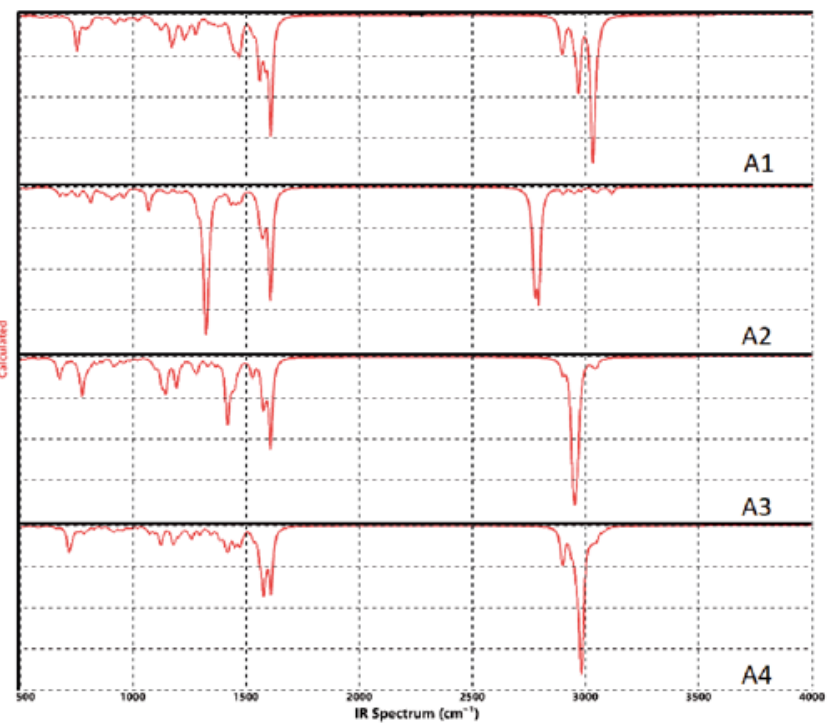

Figure 5. Calculated IR spectra for A1, A2, A3 and A4 ligands

and associated with the $\mathrm{O}-\mathrm{H}$ stretching vibrations $v(\mathrm{O}-\mathrm{H})$ is theoretically predicted at $2800-3035 \mathrm{~cm}^{-1}$. Strong characteristic peaks appear in the IR spectrum A2 ligand at 1320 and $1562 \mathrm{~cm}^{-1}$ are attributed to $v\left(\mathrm{NO}_{2}\right)$ stretching modes $^{38}$. The absorption band associated with $v(\mathrm{C}-\mathrm{Br})$ in $\mathbf{A 3}$ is calculated at $678 \mathrm{~cm}^{-1}$ and in good agreement with the experimentally determined peak at $688 \mathrm{~cm}^{-1}$.

For comparison reasons in regards to the complexes, two sets of IR spectra were computed and grouped. The first is IR spectra of CuA1, CuA2, CuA3 and $\mathbf{C u A 4}$ (Fig. 6), while the second set consists of IR spectra of CuA1, ZnA1 and MnA1, which have very similar spectral fingerprint (Fig. 7).

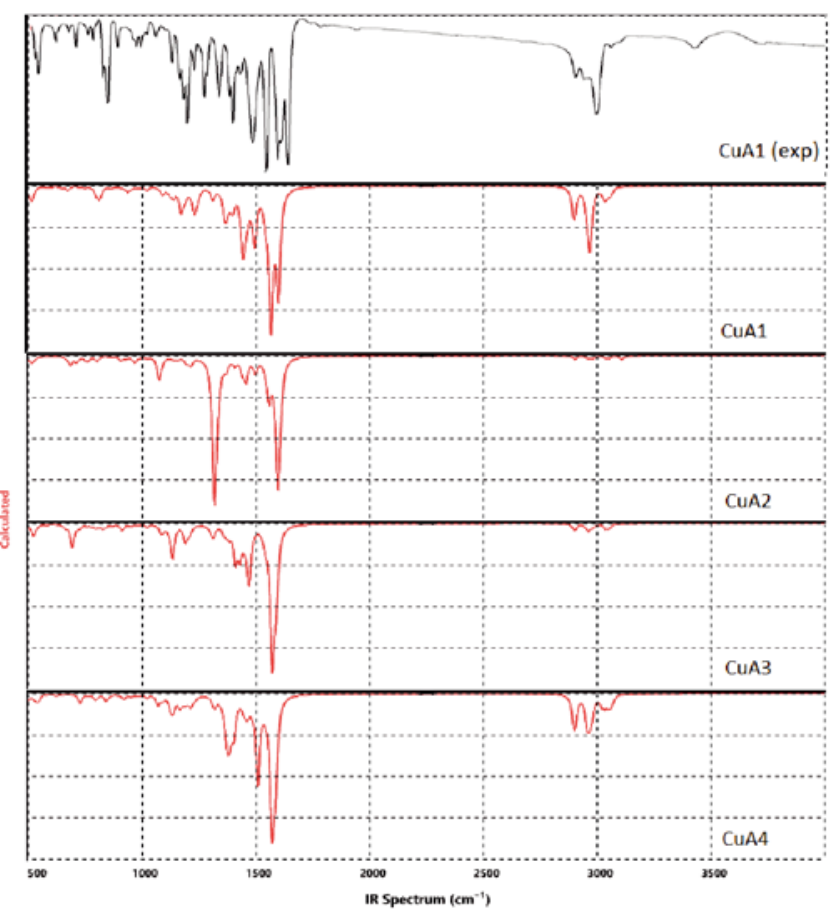

Figure 6. Calculated IR spectra for $\mathrm{CuA1}, \mathrm{CuA2}, \mathrm{CuA3}$ and CuA4 complexes. Experimental CuA1 IR spectrum is shown (top) for reference

Comparing the computed IR spectrum of CuA1 complex with the experiment (Fig. 7, top), we find the presence of an absorption band attributable to $v(\mathrm{C}=\mathrm{N})$ at $1570 \mathrm{~cm}^{-1}$ (exp. $1606 \mathrm{~cm}^{-1}$ ), a wide absorption band in 


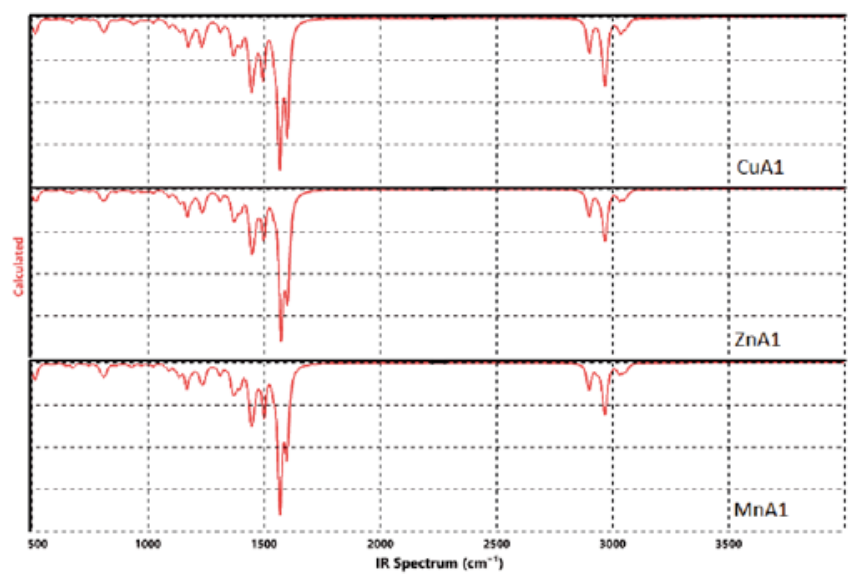

Figure 7. Calculated IR spectra for CuA1, ZnA1 and MnA1 complexes

the range of 2894-3064 $\mathrm{cm}^{-1}$ (exp. $2951 \mathrm{~cm}^{-1}$ ) attributed to the $v(\mathrm{C}-\mathrm{H})$, an absorption band in the range of 1496$1543 \mathrm{~cm}^{-1}$ (exp. $1484 \mathrm{~cm}^{-1}$ ) assigned to $v(\mathrm{C}=\mathrm{C}$ ), a band at $1392 \mathrm{~cm}^{-1}$ (exp. $1360 \mathrm{~cm}^{-1}$ ) assigned to the $v(\mathrm{C}-\mathrm{O})$ and a band at $519 \mathrm{~cm}^{-1}$ (exp. $533 \mathrm{~cm}^{-1}$ ) attributed to the $v(\mathrm{Cu}-\mathrm{O})$. In the computed IR spectrum of $\mathbf{C u A 2}$ complex, two characteristic bands appear at 1319 and $1559 \mathrm{~cm}^{-1}$ (exp. 1351 and $1530 \mathrm{~cm}^{-1}$ ) which are attributed to the $\mathrm{NO}_{2}$ vibrational modes. A distinctive peak at $692 \mathrm{~cm}^{-1}$ (exp. $698 \mathrm{~cm}^{-1}$ ) appears in the IR spectrum of $\mathbf{C u A 3}$ is attributable to $v(\mathrm{C}-\mathrm{Br})$. The spectrum of $\mathbf{C u A 4}$ complex shows a strong absorption band at $1569 \mathrm{~cm}^{-1}$ (exp. 1606 $\left.\mathrm{cm}^{-1}\right)$ assigned to $v(\mathrm{C}=\mathrm{N})$ while $v(\mathrm{C}=\mathrm{C})$ and $v(\mathrm{C}-\mathrm{O})$ appear at $1507 \mathrm{~cm}^{-1}$ (exp. $1418 \mathrm{~cm}^{-1}$ ) and $1385 \mathrm{~cm}^{-1}$ (exp. $1319 \mathrm{~cm}^{-1}$ ), respectively.

Although single crystals could not be isolated for these complexes, the analytical, spectroscopic, magnetic data and DFT calculation enable us to predict possible structures as shown in Figure 3.

\section{Anticancerous and Antiproliferative Activity}

Treatment of cell lines with increasing concentrations A3 and its metal complexes resulted in variable degrees of inhibition. The highest activity was obtained for CuA3 with $\mathrm{IC}_{50}$ values of 94.03 and $150.45 \mu \mathrm{M}$ against MCF-7 and HCT 116 cell lines, respectively (Table 4). Additionally, this compound exhibited low toxicity against Vero normal cell line with $\mathrm{IC}_{50}$ value $>320 \mu \mathrm{M}$. These results are close to those obtained with cisplatin (positive control) which inhibited both cancer cell lines at a concentration of around $58 \mu \mathrm{M}$ and showed lower toxicity against Vero cell line $\left(\mathrm{IC}_{50}>416.6 \mu \mathrm{M}\right)$.

The ligand showed activity against MCF-7 cell line $\left(\mathrm{IC}_{50}=101.89 \mu \mathrm{M}\right)$ and it was nontoxic against HCT

\begin{tabular}{|l|c|c|c|}
\hline Compounds & MCF-7 & HCT 116 & VERO \\
\hline A3 & $101.89 \pm 1.4$ & $>320$ & $>320$ \\
\hline MnA3 & $278.80 \pm 2.2$ & $>320$ & $>320$ \\
\hline ZnA3 & $167.61 \pm 0.1$ & $>320$ & $>320$ \\
\hline CuA3 & $94.03 \pm 4.7$ & $150.45 \pm 2.8$ & $>320$ \\
\hline Cisplatin & $58.32 \pm 2.1$ & $58.32 \pm 0.4$ & $>416.6$ \\
\hline
\end{tabular}

Table 4. The $\mathrm{IC}_{50}$ values $(\mu \mathrm{M})$ of the ligand and its three derivatives on three cell lines (MCF-7, HCT 116 and Vero). Data are presented using mean $\pm \mathrm{SE}$ from three independent experiments. The $\mathrm{IC}_{50}$ values were calculated using nonlinear regression in Statistical Package for the Social Sciences version 18 (SPSS Inc. Chicago, IL, USA)
116 and Vero cells $\left(\mathrm{IC}_{50}>320 \mu \mathrm{M}\right)$. On the other hand, $\mathrm{Mn}$ and $\mathrm{Zn}$ complexes showed lower activity compared with $\mathbf{C u A 3}$ which has the lowest $\mathrm{IC}_{50}$ value $(94.03 \mu \mathrm{M})$ against MCF-7 cell line (Table 4). These results indicate that adding $\mathrm{Mn}$ and $\mathrm{Zn}$ to the ligand may reduce its anticancer activity.

\section{CONCLUSIONS}

New symmetrical Schiff base tetracoordinate ligands and their $\mathrm{Cu}(\mathrm{II}), \mathrm{Mn}(\mathrm{II})$ and $\mathrm{Zn}(\mathrm{II})$ complexes have been prepared and characterized by different spectroscopic techniques and elemental analysis. The complexes were found to be neutral and paramagnetic except the zinc complexes which were found to be diamagnetic.

The optimized ground state geometries, IR and UV-Vis spectral data for the complexes were reported using DFT calculations at the B3LYP/6-31G(d) level of theory and the obtained results were in good agreement with the experimental data. The anticancerous and antiproliferative activity of the $\mathbf{A} \mathbf{3}$ ligand and its metal complexes were evaluated. The highest activity was obtained for CuA3 against MCF-7 and HCT 116 cell lines.

\section{CONFILICT OF INTEREST}

The Authors declare that there is no conflict of interest

\section{LITERATURE CITED}

1. Costes, J.P., Dahan, F., Fernandez, M.B.F., Garcia, M.I.F., Deibe, A.M.G. \& Sanmartin, J. (1998). General synthesis of 'salicylaldehyde half-unit complexes': structural determination and use as synthon for the synthesis of dimetallic or trimetallic complexes and of 'self-assembling ligand complexes'. Inorg. Chim. Acta. 274(1), 73-81. DOI: 10.1016/S0020-1693(97)05991-4.

2. Dalia, S.F., Afsan, F., Hossain, M.S., Khan, M.N., Zakaria, C., Kudrat-E-Zahan, M. \& Ali, M.H. (2018). A short review on chemistry of Schiff base metal complexes and their catalytic application. Int. J. Chem. Stud. 6(3), 2859-2866.

3. Kumar, S., Dhar, D.N. \& Saxena, P.N. (2009). Applications of metal complexes of Schiff bases-A review. J. Sci. Ind. Res. India. 68(3), 181-187.

4. Nishinaga, A., Yamada, T., Fujisawa, H., Ishizaki, K., Ihara, H. \& Matsuura, T. (1988) Catalysis of cobalt-Schiff base complexes in oxygenation of alkenes: on the mechanism of ketonization. J. Mol. Catal. 48, 249-264. DOI: 10.1016/03045102(88)85009-0.

5. Sabaa, M.W., Mohamed, R.R. \& Oraby, E.H. (2009). Vanillin-Schiff's bases as organic thermal stabilizers and co-stabilizers for rigid poly(vinyl chloride). Eur. Polym. J. 45(11), 3072-3080. DOI: 10.1016/j.eurpolymj.2009.08.018.

6. Tunçel, M. \& Serin, S. (2006). Synthesis and characterization of new azo-linked Schiff bases and their cobalt(II), copper(II) and nickel(II) complexes. Transit. Met. Chem. 31, 805-812. DOI: 10.1007/s11243-006-0074-5.

7. Pandeya, S.N., Sriram, D., Nath, G. \& De Clercq, E. (1999). Synthesis, antibacterial, antifungal and anti-HIV evaluation of Schiff and Mannich bases of isatin derivatives with 3-amino-2-methylmercapto quinazolin-4(3H)-one. Pharm. Acta. Helv. 74(1), 11-17. DOI: 10.1016/s0031-6865(99)00010-2.

8. Kelley, J.L., Linn, J.A., Bankston, D.D., Burchall, C.J., Soroko, F.E. \& Cooper, B.R. (1995). 8-Amino-3-benzyl-1,2,4-triazolo[4,3-a]pyrazines. Synthesis and anticonvulsant activity. J. Med. Chem. 38(18), 3676-3679. DOI: 10.1021/jm00018a029.

9. Pavan, F.R., Maia, P., Leite, S.R.A., Deflon, V.M., Batista, A.A., Sato, D.N., Franzblau, S.G. \& Leite, C.Q.F. (2010). Thiosemicarbazones, semicarbazones, dithiocarbazates and 
hydrazide/hydrazones: anti-mycobacterium tuberculosis activity and cytotoxicity. Eur. J. Med. Chem. 45(5), 1898-1905. DOI: 10.1016/j.ejmech.2010.01.028.

10. Upadhyay, K.K., Kumar, A., Upadhyay, S. \& Mishra, P.C. (2008). Synthesis, characterization, structural optimization using density functional theory and superoxide ion scavenging activity of some Schiff bases. J. Mol. Struct. 873, 5-16. DOI: 10.1016/j.molstruc.2007.02.031.

11. Dutta, B., Some, S. \& Ray, J.K. (2006). Thermal cyclization of 3-arylamino-3-(2-nitrophenyl)-propenal Schiff base hydrochlorides followed by triethyl phosphite mediated deoxygenation: a facile synthesis of quindolines. Tetrahedron Lett. 47(3), 377-379. DOI: 10.1016/j.tetlet.2005.11.007.

12. Chandramouli, Shivanand, M.R., Nayanbhai, T.B., Bheemachari \& Udupi, R.H. (2012). Synthesis and biological screening of certain new triazole Schiff bases and their derivatives bearing substituted benzothiazole moiety. J. Chem. Pharm. Res. 4(2), 1151-1159.

13. Chinnasamy, R.P., Sundararajan, R. \& Govindaraj, S. (2010). Synthesis, characterization, and analgesic activity of novel Schiff base of isatin derivatives. J. Adv. Pharm. Tech. Res. 1(3), 342-347. DOI: 10.4103/0110-5558.72428.

14. Chaubey, A.K. \& Pandeya, S.N. (2012). Synthesis \& anticonvulsant activity (chemo shock) of Schiff and Mannich bases of isatin derivatives with 2 -amino pyridine (mechanism of action). Int. J. Pharmtech Res. 4(2), 590-598.

15. Aboul-Fadl, T., Mohammed, F.A. \& Hassan, E.A. (2003). Synthesis, antitubercular activity and pharmacokinetic studies of some Schiff bases derived from 1-alkylisatin and isonicotinic acid hydrazide (INH). Archiv. Pharm. Res. 26(10), 778-784. DOI: $10.1007 / \mathrm{BF} 02980020$.

16. Miri, R., Razzaghi-asl, N. \& Mohammadi, M.K. (2013). QM study and conformational analysis of an isatin Schiff base as a potential cytotoxic agent. J. Mol. Mod. 19(2), 727-735. DOI: 10.1007/s00894-012-1586-x.

17. Avaji, P.G., Kumar, C.H.V., Patil, S.A., Shivananda, K.N. \& Nagaraju, C. (2009). Synthesis, spectral characterization, in-vitro microbiological evaluation and cytotoxic activities of novel macrocyclic bis hydrazine. Eur. J. Med. Chem. 44(9), 3552-3559. DOI: 10.1016/j.ejmech.2009.03.032.

18. Rao, S.N., Kathale, N., Rao, N.N. \& Munshi, K.N. (2007). Catalytic air oxidation of olefins using molybdenum dioxo complexes with dissymmetric tridentate O,N,S-donor Schiff base ligands derived from o-hydroxyacetophenone and S-benzyldithiocarbazate or S-methyldithiocarbazate. Inorg. Chim. Acta. 360(14), 4010-4016. DOI: 10.1016/j.ica.2007.05.035.

19. Iwakura, I., Ikeno, T. \& Yamada, T. (2004). Proposal for the metallacycle pathway during the cyclopropanation catalyzed by cobalt-Schiff base complexes. Org. Lett. 6(6), 949-952. DOI: $10.1021 / \mathrm{ol} 036505 \mathrm{~m}$.

20. Nishinaga, A., Yamada, T., Fujisawa, H., Ishizaki, K., Ihara, H. \& Matsuura, T. (1988). Catalysis of cobalt-Schiff base complexes in oxygenation of alkenes: on the mechanism of ketonization. J. Mol. Catal. 48, 249-264. DOI: 10.1016/03045102(88)85009-0.

21. Al-Shboul, T.M.A., Ziemann, S., Görls, H., Jazzazi, T.M.A., Krieck, S. \& Westerhausen, M. (2018). Synthesis of dipotassium 2,2'-bis(2-oxidobenzylideneamino)-4,4' -dimethyl-1,1'-biphenyl derivatives and use as ligand transfer reagent. Eur. J. Inorg. Chem. 2018(14), 1563-1570. DOI: 10.1002/ejic.201701472.

22. Al-Shboul, T.M.A., Ziemann, S., Görls, H., Krieck, S. \& Westerhausen, M. (2019). Substituted 2,2'-bis(2oxidobenzylideneamino)-4,4' -dimethyl-1,1'-biphenyl complexes of zinc. Z. Anorg. Allg. Chem. 645(3), 292-300. DOI: 10.1002/ zaac.201800404.
23. Jazzazi, T.M.A., Ababneh, T.S. \& Abboushi, E.K. (2019). Zinc(II) complexes of symmetrical tetradentate Schiff base ligands derived from 2,2'-diamino-6,6'-dibromo-4,4'-dimethyl1,1'-biphenyl-salicylaldehyde: synthesis, characterization and computational study. Jordan J. Chem.14(2), 81-87.

24. Carlin, R.B. \& Foltz, G.E. (1956). Ullmann synthesis of six dimethyldinitrobiphenyls and their reduction to the corresponding diaminodimethylbiphenyls. J. Am. Chem. Soc. 78(9), 1997-2000. DOI: 10.1021/ja01590a065.

25. Spartan'18 Wavefunction. Inc. Irvine, CA.

26. Becke, A.D. (1993). Density-functional thermochemistry. III. The role of exact exchange. J. Chem. Phys. 98(7), 5648-5652. DOI: $10.1063 / 1.464913$.

27. Becke, A.D. (1996). Density-functional thermochemistry. IV. A new dynamical correlation functional and implications for exact-exchange mixing. J. Chem. Phys. 104(3), 1040-1046. DOI: $10.1063 / 1.470829$.

28. Lee, C., Yang, W. \& Parr, RG. (1988). Development of the Colle-Salvetti correlation-energy formula into a functional of the electron density. Phys. Rev. B. 37(2), 785-789. DOI: 10.1103/PhysRevB.37.785.

29. Petersson, G.A., Bennett, A., Tensfeldt, T.G., Al-Laham, M.A \& Shirley, W.A. (1988). A complete basis set model chemistry. I. The total energies of closed-shell atoms and hydrides of the first-row elements. J. Chem. Phys. 89(4), 2193-2218. DOI: $10.1063 / 1.455064$.

30. Petersson, G.A., Tensfeldt, T.G. \& Montgomery, J.A. (1991). A complete basis set model chemistry. III. The complete basis setquadratic configuration interaction family of methods. J. Chem. Phys. 94(9), 6091-6101. DOI: 10.1063/1.460448.

31. Talib, W.H. (2017). Regressions of breast carcinoma syngraft following treatment with piperine in combination with thymoquinone. Sci. Pharm. 85(3), 27. DOI: 10.3390/ scipharm 85030027.

32. Jayaseelan, P., Prasad, S., Vedanayaki, S. \& Rajavel, R. (2016). Synthesis, characterization, anti-microbial, DNA binding and cleavage studies of Schiff base metal complexes. Arab. J. Chem. 9, 668-677. DOI: 10.1016/j.arabjc.2011.07.029.

33. Yousif, E., Majeed, A., Al-Sammarrae, K., Salih, N., Salimon, J. \& Abdullah, B. (2017). Metal complexes of Schiff base: Preparation, characterization and antibacterial activity. Arab. J. Chem. 10, 1639-1644. DOI: 10.1016/j.arabjc.2013.06.006.

34. Thaker, B.T., Surati, K.R., Oswal, S., Jadeja, R.N. \& Gupta, V.K. (2007). Synthesis, spectral, thermal and crystallographic investigations on oxovanadium(IV) and manganese(III) complexes derived from heterocyclic $\beta$-diketone and 2-amino ethanol. Struct. Chem. 18, 295-310. DOI: 10.1007/ s11224-006-9134-x.

35. Miessler, G. \& Tarr, D. (2005). Inorganic Chemistry (3rd ed). New Jersey, USA: Pearson Prentice-Hall.

36. Ababneh, T.S., Al-Shboul, T.M.A., Jazzazi, T.M.A., Alomari, M.I., Görls, H. \& Westerhausen, M. (2020). Crystallographic and computational study of the structure of copper(II) 2,2'-bis(2-oxidobenzylideneamino)-4,4'-dimethyl-1,1'-biphenyl. Transit. Met. Chem. 45. DOI: 10.1007/s11243-020-00395-8

37. Cheeseman, T.P., Hall, D. \& Waters, T.N. (1966). The colour isomerism and structure of some copper co-ordination compounds. Part XII. The crystal structure of $\mathrm{NN}^{\prime}$ (2,2'-biphenyl)bis(salicylaldiminato)copper(II). J. Chem. Soc. A 1396-1406. DOI: 10.1039/J19660001396.

38. Taha, Z.A., Ajlouni, A.M., Ababneh, T.S., Al-Momani, W., Hijazi, A.K., Al Masri, M. \& Hammad, H. (2017). DFT computational studies, biological and antioxidant activities, and kinetic of thermal decomposition of 1,10-phenanthroline lanthanide complexes. Struct. Chem. 28, 1907-1918. DOI: 10.1007/s11224-017-0975-2. 